\title{
Behavioural Aspects of Financial Decision-Making Process of Managers in Wood-Processing Enterprises
}

\section{Aspekti ponašanja menadžera drvoprerađivačkih poduzeća pri donošenju financijskih odluka}

\author{
Original scientific paper • Izvorni znanstveni rad \\ Received-prispjelo: 27. 11. 2020. \\ Accepted-prihvaćeno: 26. 5. 2021. \\ UDK: $630 * 76$ \\ https://doi.org/10.5552/drvind.2021.2047
}
(C) 2021 by the author(s). Licensee Faculty of Forestry and Wood Technology, University of Zagreb. This article is an open access article distributed under the terms and conditions of the Creative Commons Attribution (CC BY) license.

\begin{abstract}
The study is focused on behavioural aspects in the financial decision-making process of woodprocessing enterprises. The main aim was to map this topic and determine the key behavioural factors that lead management to make mistakes. Primary data on this issue were obtained from an empirical survey. The empirical survey was conducted through a questionnaire that contains questions focused on behavioural decision-making aspects. Using statistical methods, three key behavioural factors were determined. By selecting the given behavioural factors, it was established that love, hate, and sadness are the key factors that influence management behaviour and decision-making. In the real business environment, two managers working in a wood processing enterprise were chosen; they were willing to provide us with a review and opinion on the results of the survey. By analysing all the data, it has been concluded that, even though managers are trying to direct their behaviour and activities, they often do not notice the influence of these factors, and sometimes they are unable to make decisions. The managers should be able to direct their behaviour and activities, to provide self-control and take into consideration the fact that these factors are always present. Results determine the key and systematically occurring errors in the financial decision-making process, caused by the influence of the human factor. We have developed a model for activating the three key behavioural factors applied in the financial decision-making process as a tool that can help company managers not to make the wrong decisions.
\end{abstract}

Keywords: finance; behavioural finance; financial decision-making process; wood-processing enterprises; psychological factors

SAŽETAK • U ovom su radu prezentirani načini ponašanja menadžera drvoprerađivačkih poduzeća pri donošenju financijskih odluka. Glavni cilj istraživanja bio je mapirati i odrediti ključne čimbenike ponašanja koji navode menadžere na pogrešne odluke. Primarni podatci za ovo istraživanje prikupljeni su empirijskim anketiranjem koje je provedeno upitnikom s pitanjima vezanim za aspekte ponašanja pri donošenju odluka. Primjenom statističkih metoda određena su tri ključna čimbenika ponašanja. Odabirom danih obilježja ponašanja utvrdili smo da su ljubav, mržnja i tuga ključne odrednice koje utječu na menadžere pri donošenju odluka. Izabrana su dva menadžera

\footnotetext{
${ }^{1}$ Authors are professor, assistant professor and associate professor at Technical University in Zvolen, Faculty of Wood Science and Technology, Zvolen, Slovakia.
} 
iz drvoprerađivačkih poduzeća u stvarnom poslovnom okruženju koji su bili voljni dati osvrt i mišljenje o rezultatima anketa. Analizom svih podataka zaključeno je da i oni menadžeri koji su vrlo čvrsti u svojim odlukama $i$ koji pozorno kreiraju svoje ponašanje i aktivnosti najčešće nisu svjesni utjecaja danih čimbenika ponašanja, pa stoga ne mogu donijeti pravu odluku. Svaki bi menadžer trebao pravilno usmjeravati svoje ponašanje $i$ aktivnosti, imati samokontrolu i uzimati u obzir činjenicu da uvijek postoje čimbenici koji utječu na njihove odluke. Rezultati definiraju ključ i pogreške koje se sustavno pojavljuju u procesu donošenja financijskih odluka, a nastaju pod utjecajem ljudskih čimbenika. Kreirali smo model aktiviranja triju ključnih čimbenika ponašanja i procesa donošenja financijskih odluka kao alata za izbjegavanje pogrešnih odluka menadžera.

Ključne riječi: financije; financijsko ponašanje; proces donošenja financijskih odluka; drvoprerađivačka poduzé́a; psihološki čimbenici

\section{INTRODUCTION}

\section{UVOD}

Behavioural economics, currently one of the main economic directions, incorporates psychologically realistic thinking into economic decision-making analyses. In economic decisions, it is not enough to rely solely on numbers and mathematical and statistical methods, but also on memories and intuition in creating estimates of future results. Studies on investment behaviour of a number of authors at different times and places encouraged this new widely accepted inter-disciplinary field of finance: Behavioural Finance (Dervishaj, 2018; Kapoor and Prosad, 2016; Sedaghati, 2016; Shefrin, 2001; Thaler, 2005; Sewell, 2011). Behavioural aspects are not only related to psychology, they are also based on emotional and cognitive perception. The position of a manager brings responsibility, the daily pressure of duties and tasks forces him to act spontaneously and not just think about rational decisions.

Various scholars have studied factors of financial behaviour and their impact on financial decision making (Rehan and Umer, 2017; Omarli, 2017; Shu and Sulaeman, Yeung, 2016; Thaler and Sunstein, 2008; Laibson, 2009). Behavioural financing is topical, and it has begun to develop slowly. The interest of the solved problem stems from the failure to explore the present factors that affect each subject. Therefore, we decided to pay attention to it with the intent to bring some insights into this issue.

The aim of the study was to analyse behavioural factors in the financial decision-making, and consequently to determine the key and systematically occurring errors in the financial decision-making process, caused by the influence of the human factor, as a starting point for preventing wrong financial decisions in the wood-processing industry. Our findings are summarized in the developed model that can eliminate wrong decisions of company managers.

\subsection{Theoretical fundamentals}

1.1. Teorijske pretpostavke

Traditional finance is based on neoclassical economy. It is assumed that individuals are against risk, have perfect rationality and focus on maximizing the function of personal benefits. Therefore, efficient markets arise. Behavioural financing notes that individuals can sometimes have risky behaviours (FAW, 2018).
The traditional theory of corporate finance shares several features with neoclassical financial economics. The manager is focused on maximizing shareholder wealth (Shefrin, 2001). Neoclassical financing theories rely on the skills and motivation of managers themselves, while they behaviourally monitor the behaviour of markets, not just individuals (Ross, 2004). Traditional financing monitors the behaviour of individuals - rational managers, investors and market participants. This leads to markets where prices reflect all available relevant information (Sedliačiková et al., 2015).

Behavioural finance recognizes that the way information is presented to participants has a major impact on decision-making and can lead to emotional and cognitive biases. As decisions are not always optimal, this leads to markets that are temporarily or permanently inefficient (FAW, 2018). Proper economic decisionmaking of individuals is influenced by limited human rationality, social priorities, and a lack of human selfcontrol (Thaler and Sunstein, 2008). Behavioural economics is known as a combination of psychology and economics for understanding finance (Laibson, 2009). Behavioural finance is the result of the structure of three different sciences (Ricciardi and Simon, 2000):

- psychology as a science that analyses the processes of behaviour and thinking, such as the processes of physical, mental and external environment of a person,

- finance as a system of creating and using resources, - sociology as a science of the social behaviour of a person or a group of people.

Behavioural theories assume that the behaviour of an individual or group is influenced by previous learning. It is about acquiring certain forms of behaviour (Verešová et al., 2014). Behavioural finance is associated with psychological and sociological factors that influence the decisions of financial entities (Shefrin, 2001). Sewell (2011) explains behavioural finance as the influence of psychology on the behaviour of financial professionals, who subsequently have an impact on the market itself. Kahneman and Tversky (1979) noted that the behaviour of an individual in theory differs from practice, and classical financial models cannot explain or predict all financial decisions. Economic rationality in behavioural finance is criticized. Behavioural finance became popular after 2002, when Kahneman (2002) won the Nobel Prize in Economics for the behavioural theory, where he integrated knowledge from psychological research in the field of economics that 
focused on human behaviour and analysis of the human judgment. Behavioural finance is based on research into human and social recognition and the study of emotional tolerance. It seeks to identify and understand economic decisions. Classical financial behaviour is limited by human rationality, behaviourally explaining the psychological effect on financial markets and activities. It claims that financial phenomena are better explained due to the fact that financial market participants are not rational and their decisions are not limited (Bikas et al., 2013). Behavioural finance is a type of modern financial theory that states that investors and other interest groups and financial market participants do not behave rationally. There is also the influence of a lot of information on decision-making (Thaler and Sunstein, 2008). Thaler and Sunstein (2008) say that people create financial evaluations using internal calculations and formulas. Not only are people irrational, but this irrationality can sometimes be predicted in advance. Doing business properly and behaving economically depends on people. Behavioural finance is the study of how the phenomenon of psychology affects financial behaviour (Shefrin, 2005). An essential part of behavioural finance is to observe how classical financing and behavioural financing differ in rationality. Decision-making is not only dependent on a careful evaluation of information or statistics, but also on rational decisions. It is a matter of shortening the process of making one's own decision, but only at the expense of less effort in making mathematical or statistical calculations (Lehrer, 2011).

According to the Baker et al. (2004), there are two different approaches to finance:

- irrational managers and an efficient/productive market,

- limited rationality - irrational investors and rational managers.

The first approach - irrational managers - focuses on the analysis of the irrational behaviour of managers in the context of an efficient financial market ${ }^{\circledR}$ excessively optimistic (Fairchild, 2010). Weinstein (1980) describes optimism as people's belief that they are more likely to experience future positive life events and less likely to experience negative situations. In terms of managerial decisions, these decisions play against shareholders/investors. These are intentional and unintentional decisions that reduce value. These are the decisions that intentionally reduce the value of the company, in which managers try to bypass shareholders, and this leads to conflicts that can be resolved by adjusting incentives. However, these decisions do not arise due to different interests between shareholders and managers. These are the consequences of managers' mistakes. These mistakes occur due to psychological aspects and should be preceded by training in the area of management and education (Fairchild, 2010).

The approach of irrational managers is currently less developed. It assumes that the managers' behaviour is defined, but preserves the rationality of investors even if they limit the management mechanisms that they can use to restrict managers. It monitors prej- udices of optimism and overconfidence. The simple model shows prejudices of senior managers who believe that their companies are underestimated, encourage overinvestment from internal sources and show preferences for internal and external financing, especially by internal capital. As in the case of investor irrationality, the real economic losses associated with managerial irrationality have yet to be quantified but are significant (Baker et al., 2007).

By irrational managerial behaviour, we mean behaviour that deviates from rational expectations and expected maximization of utility value. The manager believes that he is actually close to maximizing the fixed value. In order to have fewer rational managers, corporate management must limit their ability to make rational decisions (Eckbo, 2007).

In regard to the financial policy, an optimistic manager never sells shares unless he has to. If there is an upper limit of the leverage effect (e. g. greater than zero), optimism predicts "accumulation". Financing decisions: the manager relies on internal capital and debt but uses only his own resources. This is his last chance (Baker et al., 2007).

The second approach - irrational investors - focuses on situations when investors are systematically irrational and rationally well-informed thanks to managers. This approach assumes that managers will be able to distinguish between price and intrinsic value (Baker et al., 2004). According to Graham and Harvey (2001), price represents what investors pay and intrinsic value is what they get. We are talking about the rational goals of managers in irrational markets. Rational managers maintain a balance between the three goals. These are market timing, supply and an increase of the intrinsic value. Market timing refers to decisions aimed at the proper valuation of, for example, the issue of overvalued or repurchased undervalued shares. Supply refers to decisions aimed at rising stock prices above intrinsic value. Increasing intrinsic value is a clear matter - it is about increasing the market value of the company (Fairchild, 2010).

The possibility of learning from mistakes or experience is characteristic for behavioural financing. Managers or other executives are people who may be influenced by their own optimism and overestimation of certain future events. It is well known that self-confidence can lead to mistakes in decision making and overconfident managers are able to underestimate the risk of future results (Baker and Nofsinger, 2010).

The Slovak Republic is relatively independent of importing the natural resources, being built on a domestic resource base of sustainable character. Therefore, it can permanently show an active balance of foreign trade. Regarding the positive situation related to natural resources, their suitable geographic location, and their acceptable energetic demands for processing wood, the wood-processing industry represents an important field of industry for the Slovak national economy, thus enabling further development of small and medium enterprises (Hajdúchová et al., 2016). Woodprocessing industry (WPI) is composed of the wood, 
furniture, and pulp and paper industries. These are based on processing wood, i.e. domestic ecological resource (Halaj et al., 2018).

The wood-processing industry can positively assess the development of labour productivity. It is the most significant in the pulp and paper industry, where long-term growth above the average of industrial production is recorded, especially in periods with high inflows of foreign direct investment into the mentioned sector (Merková et al., 2011). However, the wood-processing industry of Slovakia notes no innovation development focused on the increase of the competitiveness of production and efficiency, and without providing financial resources needed to implement innovative plans, it can expect a significant decrease in the competitiveness and long-term recession (Merková and Drábek, 2010). The share of R\&D capacities is gradually reduced, and thus it fails to engage the capacities into innovative projects (Merková et al., 2012). The bioeconomy strategy, launched by the European Commission, and the transition to a stronger, circular and low-carbon economy have posed new actions and requirements towards a greater and more sustainable use of natural resources by sustainably increasing the primary production and conversion of waste into value-added products, enhanced production and resource efficiency (Antov et al., 2020).

\subsection{Objectives and hypotheses}

1.2. Ciljevi i hipoteze

The aim of the work was to develop a model of key behavioural factors that cause errors in the financial decision-making of managers in wood-processing enterprises. The essence was to determine the key, systematically occurring errors in the financial decisionmaking process, caused by the influence of the human factor, as a starting point for preventing wrong financial decisions.

The main hypothesis can be defined as follows: We assume that the model of key behavioural aspects will be suitable for identifying the main causes of differences in decision-making in neoclassical and behavioural financing, and will serve as a starting point for preventing wrong financial decisions.

We have added five partial hypotheses to the main hypothesis, which are as follows:

$H_{1}$ : We assume that managers do not observe their decision-making behaviour and are unable to proceed with the self-control in thinking.

Richard Thaler (2005) studied the behaviour of people and found out that that people do things that should not happen when making decisions in classical economics. He wanted to find explanations and wrote a study called Dump Stuff People Do. He was also inspired by Kahneman and Tversky (1979), and so he became one of the fathers of behavioural economics (Záborský, 2017).

$\mathrm{H}_{2}$ : We assume that human behaviour is important in evaluating economic decisions.

Adam Smith (2012) claimed this idea and described it in the work Theory of Moral Sentiments. Behavioural financing is the subject of many empirical observations, and the author's effort was to explain the deviations of behavioural from rational decision-making.

$\mathrm{H}_{3}$ : We assume that people are rational and their thinking is reasonable. Emotions such as fear, love or hate are a source of cases when people change their behaviour and deviate from rationality.

Tversky and Kahneman (1974) described systematic errors in the thinking of normal people and at the same time analysed the origin of such errors in the mechanism of cognition. Thus, they found that emotional and psychological factors are a source of change in the behaviour of people, but only when it comes to borderline situations of decision-making and understanding of something unknown. In this case, we can also apply it to the target decision subjects, i. e. managers of enterprises.

$\mathrm{H}_{4}$ : We assume that the key factors that most influence the managers in decision-making are knowledge as a cognitive factor, certainty as psychological and happiness as an emotional factor.

Standard economic theory is designed to offer mathematically set solutions and to perceive man as an economically rational subject. They are based on idealized financial behaviour. Behavioural finance, in turn, attempts to imitate the phenomenon of the human psyche and is based on observed behaviour (Pompian, 2006).

Akerlof and Shiller (2010) argue that behavioural finance has emerged as a new trend in economics that focuses on the economic aspects of deviations from the rational behaviour of subjects, especially the impact of cognitive distortions, psychological and emotional states of the subject. The key factors of human behaviour that influence decision making are:

- Emotional: love, hate, sadness, happiness, helplessness, panic, depression, despair, anxiety.

- Cognitive: knowledge, learning, ability to concentrate attention, ability to know, logical thinking, human character, short-term and long-term memory processes.

- Psychological: power, safety, security, personality, shame, self-esteem, freedom, self-realization, friendship, health, attractiveness.

$H_{5}$ : We assume that the model of identified key psychological, cognitive and emotional factors will become a tool for correct decision-making of company managers.

The hypothesis can be proved because a comprehensive theoretical analysis followed the issue of behavioural aspects of financial decision-making of company managers and clearly showed that the manager thinks rationally if he does not take into account the state in which he is at the moment of making the decision.

\section{MATERIALS AND METHODS} 2. MATERIJALI I METODE

The schedule in Table 1 presents the methodology of the whole research, describing interconnections and sequence of goals, hypotheses, research methods and ways of testing. 
Table 1 Connection and continuity of objectives and hypotheses of the work

Tablica 1. Veze i slijed ciljeva i hipoteza u radu

\begin{tabular}{|c|c|c|c|}
\hline $\begin{array}{l}\text { Objective } \\
\text { Cilj }\end{array}$ & & \begin{tabular}{|l|} 
Method \\
Metoda
\end{tabular} & \begin{tabular}{|c|} 
Way of testing \\
Način testiranja
\end{tabular} \\
\hline \multicolumn{4}{|c|}{$\begin{array}{l}\text { O1: Data collection in the first part of the work is used to examine the current state of the issue at home and abroad with the } \\
\text { focus on behavioural aspects of financial decision-making of company managers, concretization of differences between neo- } \\
\text { classical and behavioural financing and definition of financial management tasks. } \\
\text { O1: Prikupljanje podataka prvi je dio istraživanja kako bi se ispitalo trenutačno stanje problema u zemlji i inozemstvu, uz } \\
\text { usmjerenost na aspekte ponašanja menadžera poduzeća pri donošenju odluka, odredile razlike između neoklasičnog finan- } \\
\text { ciranja i financiranja na temelju ponašanja te da bi se definirale zadaće financijskog menadžmenta. }\end{array}$} \\
\hline \multirow{2}{*}{$\begin{array}{l}\text { O2: Based on an empirical survey } \\
\text { conducted in the form of a question- } \\
\text { naire in the practice of Slovak } \\
\text { enterprises, analyse the issue of } \\
\text { cognitive, psychological and } \\
\text { emotional influences on financial } \\
\text { decision-making of managers. } \\
\text { O2: Na osnovi empirijskog } \\
\text { istraživanja putem upitnika u } \\
\text { slovačkim poduzećima, analizirano } \\
\text { je stanje s obzirom na kognitivne, } \\
\text { psihološke i emocionalne utjecaje na } \\
\text { donošenje financijskih odluka } \\
\text { menadžera. }\end{array}$} & $\begin{array}{l}H_{1}: \text { We assume that managers do not observe } \\
\text { their decision-making behaviour and are } \\
\text { unable to proceed with the self-control in } \\
\text { thinking. } \\
H_{1} \text { : Pretpostavlja se da menadžeri ne } \\
\text { obraćaju pozornost na svoje ponašanje pri } \\
\text { donošenju odluka i da ne mogu zadržati } \\
\text { samokontrolu u razmišljanju. }\end{array}$ & $\begin{array}{l}\text { Question- } \\
\text { naire } \\
\text { (question } \\
\text { number 10) } \\
\text { upitnik } \\
\text { (pitanje } \\
\text { broj 10) }\end{array}$ & $\begin{array}{l}\text { Descriptive and } \\
\text { graphical methods } \\
\text { opisne i grafičke } \\
\text { metode }\end{array}$ \\
\hline & $\begin{array}{l}\mathrm{H}_{2} \text { : We assume that human behaviour is } \\
\text { important in evaluating economic decisions. } \\
\mathrm{H}_{2} \text { : Pretpostavka je da je pri vrednovanju } \\
\text { financijskih odluka važno ljudsko ponašanje. }\end{array}$ & $\begin{array}{l}\text { Question- } \\
\text { naire } \\
\text { (question } \\
\text { number 11) } \\
\text { upitnik } \\
\text { (pitanje } \\
\text { broj 11) }\end{array}$ & $\begin{array}{l}\text { Descriptive and } \\
\text { graphical methods } \\
\text { opisne i grafičke } \\
\text { metode }\end{array}$ \\
\hline
\end{tabular}

O3: Thanks to empirical research conducted through Questionnaires, evaluate and examine the effects of behavioural factors on the thinking of company managers and their influence in decision-making through mathematical and statistical methods. O3: Na osnovi empirijskog istraživanja putem upitnika trebalo je vrednovati i ispitati utjecaje čimbenika ponašanja na način razmišljanja menadžera te putem matematičkih i statističkih metoda utvrditi njihov utjecaj na donošenje odluka.

O4: Identify the key, systematically appearing errors in financial decision-making of managers due to the impacts of human factors.

O4: Identificirati ključne pogreške

koje se sustavno pojavljuju pri

donošenju financijskih odluka menadžera pod utjecajem ljudskog čimbenika.

O5: Develop a comprehensive model of systematically occurring errors in decision-making of company managers, which will serve as a tool for correct decision-making O5: Kreirati sveobuhvatan model pogrešaka koje se sustavno pojavljuju pri donošenju odluka menadžera, koji će poslužiti kao alat za ispravljanje pogrešaka pri donošenju odluka
$\mathrm{H}_{3}$ : We assume that people are rational and their thinking is reasonable. Emotions such as fear, love or hate are a source of cases when people change their behaviour and deviate from rationality

$\mathrm{H}_{3}$ : Pretpostavka je da su ljudi racionalni $i$

da razmišljaju razumno. Emocije poput straha, ljubavi ili mržnje razlozi su zbog kojih ljudi mijenjaju način ponašanja $i$ odstupaju od racionalnog postupanja.

$\mathrm{H}_{4}$ : We assume that the key factors that most influence the managers in decision-making are knowledge as a cognitive factor, certainty as psychological and happiness as an emotional factor.

$H_{4}:$ Pretpostavka je da su ključni čimbenici

koji utječu na racionalno ponašanje

menadžera pri donošenju odluka znanje kao

kognitivni čimbenik, sigurnost kao psihološki

čimbenik i sreća kao emocionalni čimbenik.

$H_{5}$ : We assume that the model of identified

key psychological, cognitive and emotional factors will become a tool for correct decision-making of company managers. $H_{5}$ : Pretpostavka je da će model identificiranih ključnih psiholoških, kognitivnih $i$ emocionalnih čimbenika postati alat za izbjegavanje donošenja pogrešnih odluka menadžera
Question- $\quad$ Descriptive and

naire graphical methods

(question opisne i graficke

number 9) metode

upitnik

(pitanje

broj 9)

-

Question- $\quad$ Contingency tables,

naire $\quad$ Pearson's chi-square

(question test, Cramer's V and

number 7) Pearson's contingency

upitnik coefficient $\mathrm{C}$

(pitanje tablica predvidivosti,

broj 7) Pearsonov $\chi^{2}$-test,

Cramerov V-koeficijent

i Pearsonov koeficijent

predvidivosti $C$ 


\subsection{Research sample}

\subsection{Uzorak istraživanja}

The basic set was made of 2549 enterprises from the wood-processing industry - according to the classification SK NACE. The enterprises were from the following sectors: 16 - Manufacture of wood and wood products, 17 - Manufacture of paper and paper products; and 31 - Manufacture of furniture. The questionnaire survey was conducted during January and February 2020. We determined the size of the research sample on the basis of a mathematical relation. In our case, the research sample or sample size will represent the minimum number of respondents who were included in the research.

$$
n \geq \frac{\left(z^{2} \cdot p \cdot q\right)}{\Delta^{2}}
$$

The variable $n$ in the formula represents the minimum number of respondents; the variable $z$ represents the reliability coefficient; the variable $p$ and $q$ represent the percentage numbers of addressed respondents. These two values express the number of those respondents who understand or do not understand the issue (Kozel et al., 2006).

The research methodology offers several ways of compiling a sample. We have chosen a purely random selection. The set of respondents had to be divided into two halves. The distribution of the set of respondents is related to the variables $p$ and $q$. The product of their values must be maximal (50\%: $50 \%$ ). The variable $\Delta$ represents a value that means the maximum acceptable error (Kozel et al., 2006).

To reach higher reliability of the research, at the level of $95.4 \%$, we decided to state the value of the variable $z=2$. The value of the maximum error to identify the representativeness of the sample was set to $5 \%$ (Kozel et al., 2006).

$$
n=\frac{2^{2} \cdot 0.5 \cdot 0.5}{0.05^{2}}=400
$$

Sample size should be represented by at least 400 respondents (Kozel et al., 2006). 403 respondents participated in the questionnaire survey. The total number of addressed respondents was 2549 . Thus, the return rate of the questionnaires was $15.81 \%$, which presented 403 completed questionnaires from the enterprises in the field of wood-processing industry.

\subsection{Research questions}

\subsection{Pitanja u istraživanju}

The research questionnaire consisted of 11 questions. This paper presents the research methodology and solution conclusions focused on two main and three complementary questions from the questionnaire. We also defined the types of questions used in the survey, because the type of question is important for choosing the statistical method.

Question 4: the objective was to select subjects in terms of their position within the enterprise. This question became the basis for the compilation of the questionnaire. Question 4 was close-ended, selective, poly- tomy, with the possibility of choosing one of three variants: manager, employee, owner.

We focused on the structure of the research sample. Question 4 is significant to determine a model of key behavioural aspects in the financial decision-making process. Given that, the work is focused on the issue of behavioural factors from the perspective of managers of wood-processing enterprises. This question helped us to select the subjects and then focus only on them.

Research question 7 was focused on determining the key behavioural factors that have a decisive influence on the change of managers' behaviour and, due to these changes, can also cause wrong decisions.

Question 7: Which of the following cognitive, psychological and emotional factors most influence the rational behaviour of managers in decision-making? Question 7 was close-ended, named, polytomy, with a choice of several variants - behavioural factors.

Three categories of behavioural factors were mentioned in this question - cognitive, psychological and emotional. We have selected a few examples for each category. In this question, it was necessary to follow the degree of dependence between the job position of respondents and the given categories of factors. Thus, individual behavioural factors became the second variable for the statistical determination of dependence.

Complementary questions were the following:

Question 9: In the case of borderline (unknown) decision-making situations, emotions such as fear, love or hate are a source of change in my behaviour.

Question 10: I control my behaviour in decisionmaking so that self-control is present in thinking.

Question 11: I think that my behaviour is one of the important aspects in explaining economic decisions.

Bipolar Likert scaling method was used in the above questions 9, 10 and 11 and the format of a typical five-level Likert item was applied (Likert, 1932):

- Strongly disagree

- Disagree

- Neither agree nor disagree

- Agree

- Strongly agree

Using statistical methods, we wanted to point out significant dependencies between:

- Job position (question 4 in the first part),

- Behavioural factors (question 7a, 7b, 7c in the second part of the questionnaire).

\subsection{Research methods}

\subsection{Metode istraživanja}

The following selected statistical methods were applied in the research:

- two-dimensional classification of the statistical file based on categorical characters - contingency tables,

- dependence of categorical features - Pearson's chisquare test and degree of dependence - Cramer's V and Pearson's contingency coefficient $\mathrm{C}$. 
We subjected the obtained primary data to mathematical-statistical analysis, where the results of the questionnaire survey were transformed into a contingency table in the text editor Microsoft Excel. We filtered the question related to the job position and the question about behavioural factors into the table. Using the statistical software STATISTICA 10, we examined the contingency and association of individual items. Pacáková et al. (2009) promote the application of Pearson's chi-square test at a significance level of $5 \%$ for contingency and association research, and the application of Cramer's V and Pearson's contingency coefficient $\mathrm{C}$ for associations.

Association presents a dependence between two alternative categorical characters, where contingency is a dependence between two categorical characters, of which at least one character has more than two variations (Pacáková et al., 2009). When verifying the dependence/independence of the two qualitative characters, in this case the job position and individual behavioural factors, we had to get the data from the two-dimensional sample set in a contingency table. The association of categorical characters was tested using the Pearson's chi-square test and the degree of dependence using the Cramer's V and Pearson's contingency coefficient $\mathrm{C}$.

The Pearson's chi-square (c2) test is a universal test for discrete and continuous distribution functions with a sufficiently large range $(n)$. Pearson's chi square or good fit test is based on a frequency table. This frequency table tests the null hypothesis (Budíková et al., 2010). The comparison of actually found and theoretical numbers is the basic idea of Pearson's chi-square good fit test. The null hypothesis compared to the alternative hypothesis can be verified by a testing characteristic. It is valid (Pacáková et al., 2009):

- $H_{0}$ : there is no dependence between two categorical characters,

- $H_{1}$ : there is a dependence between two categorical characters (there is contingency).

If the $\mathrm{p}$-value is lower than the significance level of $5 \%$, we reject $H_{0}$ and accept $H_{1}$, and we speak of a statistically significant dependence i. e. contingency and association. We consider the statistical significance and the results are applicable. If the p-value is equal to or higher than $5 \%, H_{0}$ cannot be rejected. The difference between the observed and expected frequencies is the cause of random selection, and we do not speak about statistical significance between the characters (Pacáková et al., 2009).

Cramer's $V$ and Pearson's contingency coefficients $C$ indicate the degree of dependence. The coefficient takes values between 0 and 1 . The closer it is to 1 , the stronger is the dependence between the two characters. On the contrary, the closer it is to 0 , the weaker is the dependence (Schmidtová and Vacek, 2013). The significance of the values of the Cramer's coefficient is defined by a scale: between 0 and 0.1 - negligible dependence, between 0.1 and 0.3 - weak dependence, between 0.3 and 0.7 - medium dependence, between 0.7 and 1 - strong dependence (Pacáková et al., 2009).

\section{RESULTS}

\section{REZULTATI}

\subsection{Findings from statistical analysis}

3.1. Rezultati statističke analize

We tested 27 behavioural factors that influence decision making:

- Emotional: love, hate, sadness, happiness, helplessness, panic, depression, despair, anxiety.

- Cognitive: knowledge, skills, ability to concentrate attention, ability to know, logical thinking, human character, short-term and long-term memory processes.

- Psychological: power, safety, security, personality, shame, self-esteem, freedom, self-realization, friendship, health, attractiveness.

Through Pearson's chi-square test, statistical dependences of two variables were found. By selecting individual dependencies, 11 factors that are statistically dependent on the job position were determined. Further on, the degree of dependence was followed through the Cramer's $V$ and Pearson's contingency coefficient $C$. Here we examined how the dependence manifests itself, whether the results are applicable and whether they are statistically significant, and determined dependence between factors. Our selection narrowed down to 4 factors: the ability to concentrate attention, love, hate, sadness. At the same time, it can be stated that these factors and the position of the manager in the company are key factors for changing behaviour. The table of residual frequencies showed that the manager is influenced by these four factors. One factor is from the category of cognitive factors and others from the category of emotional factors (Table 2).

Dependence of job position and influence of behavioural factors on financial decision-making process (O4 and O7a - ability to concentrate attention) (Table 3 ): We reject the $H_{0}$ with the risk of the $5 \%$-error that there is no dependence between the influence of behavioural factors on the job position and we accept the $H_{1}$. The reliability of our decision to reject $H_{0}$ is confirmed by the fulfilment of the condition of good approximation. The approximation can be used when missing information makes it impossible to obtain an accurate result. The value of Cramer's V at the level of 0.5894 represents a medium dependence between the job position of the respondents and the influence of behavioural factors on the financial decision-making process. Furthermore, it can be stated that the ability to concentrate attention influences the behaviour of individual subjects and can also lead to wrong decisions. From the

Table 2 Residual frequencies (ability to concentrate attention)

Tablica 2. Frekvencije osipanja (mogućnost koncentracije)

\begin{tabular}{|c|c|c|c|c|}
\hline \multirow{4}{*}{} & \multicolumn{4}{|c|}{$\begin{array}{c}\text { Observed minus expected frequencies } \\
\text { Dobivene manje očekivane frekvencije }\end{array}$} \\
\cline { 2 - 5 } & $\begin{array}{c}\text { Manager } \\
\text { Menadžer }\end{array}$ & $\begin{array}{c}\text { Owner } \\
\text { Vlasnik }\end{array}$ & $\begin{array}{c}\text { Employee } \\
\text { Zaposlenik }\end{array}$ & Line (sums) \\
\hline $\mathbf{0}$ & 5.51613 & -4.81886 & -0.697270 & 0.00 \\
\hline $\mathbf{1}$ & -5.51613 & 4.81886 & 0.697270 & 0.00 \\
\hline
\end{tabular}


Table 3 Dependence $\mathrm{O} 4$ and $\mathrm{O} 7 \mathrm{a}$ and ability to concentrate attention

Tablica 3. Ovisnost O4 i O7a o mogućnosti koncentracije

\begin{tabular}{|l|c|c|c|}
\hline \multirow{2}{*}{\multicolumn{1}{|c|}{ Statistics / Statističke metode }} & \multicolumn{3}{c|}{$\begin{array}{c}\text { Statistics: O4 and O7a Ability to concentrate attention } \\
\text { Statistika: O4 i O7 s mogućnośću koncentracije }\end{array}$} \\
\cline { 2 - 4 } & Chi-square / $\chi^{2}$ & $\boldsymbol{D f}$ & $\boldsymbol{p}$ \\
\hline Pearson's Chi square / Pearsonov $\chi^{2}$-test & 139.9888 & 2 & $<0.00001$ \\
\hline $\mathrm{M}-\mathrm{V}$ chi square / M-V $\chi^{2}$-test & 41.92583 & 2 & $<0.00001$ \\
\hline Phi / $\varphi$ & 0.5893782 & \multicolumn{2}{|c}{} \\
\hline Contingency coefficient / koeficijent predvidivosti & 0.5077514 \\
\hline Cramer's V/ Cramerov V-test & 0.5893782 \\
\cline { 1 - 2 }
\end{tabular}

residual frequencies for the respective factor it results that, while the manager is not influenced by the ability to concentrate attention, the owner and employee are.

Dependence of job position and influence of love on financial decision-making process (O4 and $\mathrm{O} 7 \mathrm{c})$ : At the significance level of $5 \%, H_{0}$ can be rejected even with this factor and the alternative hypothesis $\mathrm{H}_{1}$ can be accepted. The value of Cramer's $V$ is 0.2114 , which represents a weak dependence between the job position of respondents and the influence of love on the financial decision-making process (Table 4). There is also statistical significance between the two variables. Residual values show that, while a manager assumes the effect of love on a change in his behaviour, employees and owners are not influenced by this behavioural factor.

Dependence of job position and influence of hate on financial decision-making process (O4 and $\mathrm{O} 7 \mathrm{c})$ : At the level of $5 \%$ significance, $H_{0}$ with this factor can also be rejected, where the basis was to keep the condition of good approximation since the value of Pearson's chi-square is 0.02797 (Table 5). In this way, it can be said that there is dependence and thus the influence of hate as an emotional factor affects the job position of the addressed subjects. The important thing is that through residual frequencies, it was established that the manager is influenced by hate in decision-making and that it changes his behaviour, which is not the case with the owner and employee. While the manager is affected by hate, other subjects are not.

Dependence of job position and influence of sadness on financial decision-making process (O4 and $\mathrm{O} 7 \mathrm{c}$ ): In examining behavioural factors, it was observed that sadness is the last factor that influences the behaviour of subjects in different job positions (Table 6). This factor is one of the emotional behavioural factors. Based on the expected frequencies, it can be concluded that there is also statistical significance between the variables and that the results are applicable (Table 7). It can also be determined that this factor affects the behaviour of a particular subject - the company manager. This can be seen this through the table of residual frequencies. While the manager is affected by sadness, the employee and company owner are not.

To understand the whole research and model construction and the answers to all the hypotheses given in the conclusion, some other results can be added. At the same time, however, we decided to omit the results of other questions with no statistically significant result, where the analysis did not lead to essential conclusions.

Table 4 Dependence $\mathrm{O} 4$ and $\mathrm{O} 7 \mathrm{c}$ love

Tablica 4. Ovisnost $\mathrm{O} 4 \mathrm{i}$ O7c o ljubavi

\begin{tabular}{|l|c|c|c|}
\hline \multirow{2}{*}{\multicolumn{1}{|c|}{ Statistics / Statističke metode }} & \multicolumn{2}{c|}{ Statistics: O4 and O7c love } \\
& \multicolumn{2}{|c|}{ Statistika: O4 i O7 s ljubavlju } \\
\cline { 2 - 3 } & Chi-square / $\chi^{2}$ & $\boldsymbol{d f}$ & $\boldsymbol{p}$ \\
\hline Pearson's Chi square / Pearsonov $\chi^{2}$-test & 18.01184 & 2 & 0.00012 \\
\hline $\mathrm{M}-\mathrm{V}$ chi square / M-V $\chi^{2}$-test & 16.09091 & 2 & 0.00032 \\
\hline Phi / $\varphi$ & 0.2114105 & \\
\hline Contingency coefficient / koeficijent predvidivosti & 0.2068388 \\
\hline Cramer's V / Cramerov V-test & 0.2114105 \\
\hline
\end{tabular}

Table 5 Dependence $\mathrm{O} 4$ and $\mathrm{O} 7 \mathrm{c}$ hate

Tablica 5. Ovisnost O4 i O7c o mržnji

\begin{tabular}{|c|c|c|c|}
\hline \multirow[t]{2}{*}{ Statistics / Statističke metode } & \multicolumn{3}{|c|}{$\begin{array}{l}\text { Statistics: } 04 \text { and } 07 \mathbf{c} \text { hate } \\
\text { Statistika: } 04 \text { i } 07 \text { s mržnjom }\end{array}$} \\
\hline & Chi-square $/ \chi^{2}$ & $d f$ & $p$ \\
\hline Pearson's Chi square / Pearsonov $\chi^{2}$-test & 7.152895 & 2 & 0.02797 \\
\hline $\mathrm{M}-\mathrm{V}$ chi square $/ M-V \chi^{2}$-test & 10.10468 & 2 & 0.00639 \\
\hline Phi / $\varphi$ & 0.1332258 & & \\
\hline Contingency coefficient / koeficijent predvidivosti & 0.1320590 & & \\
\hline Cramer's V/ Cramerov V-test & 0.1332258 & & \\
\hline
\end{tabular}


....... Sedliačiková, Kánová, Drábek: Behavioural Aspects of Financial Decision-Making...

Table 6 Dependence $\mathrm{O} 4$ and O7c sadness

Tablica 6. Ovisnost O4 i O7 o tuzi

\begin{tabular}{|c|c|c|c|}
\hline \multirow{2}{*}{ Statistics / Statističke metode } & \multicolumn{3}{|c|}{$\begin{array}{l}\text { Statistics: } \mathbf{O 4} \text { and } 07 \mathbf{c} \text { sadness } \\
\text { Statistika: } 04 \text { i } O 7 \mathrm{~s} \text { tugom }\end{array}$} \\
\hline & Chi-square $/ \chi^{2}$ & $d f$ & $p$ \\
\hline Pearson's Chi square / Pearsonov $\chi^{2}$-test & 15.88575 & $\mathrm{df}=2$ & 0.00036 \\
\hline $\mathrm{M}-\mathrm{V}$ chi square $/ M-V \chi^{2}$-test & 14.86026 & $\mathrm{df}=2$ & 0.00059 \\
\hline Phi / $\varphi$ & 0.1985415 & & \\
\hline Contingency coefficient / koeficijent predvidivosti & 0.1947404 & & \\
\hline Cramer's V / Cramerov V-test & 0.1985415 & & \\
\hline
\end{tabular}

Table 7 Residual frequencies (Dependence O4 and O7c: love, hate, sadness)

Tablica 7. Frekvencija osipanja (ovisnost O4 i O7: ljubav, mržnja, tuga)

\begin{tabular}{|c|c|c|c|c|}
\hline & \multicolumn{4}{|c|}{ Observed minus expected frequencies / Dobivene manje očekivane frekvencije } \\
\hline & \multicolumn{4}{|c|}{ Dependence O4 and O7c: love / Ovisnost O4 i O7: ljubav } \\
\hline & Manager / Menadžer & Owner / Vlasnik & Employee / Zaposlenik & Line (sums) \\
\hline 0 & -9.38710 & 5.72953 & 3.65757 & 0.00 \\
\hline \multirow[t]{3}{*}{1} & 9.38710 & -5.72953 & -3.65757 & 0.00 \\
\hline & \multicolumn{4}{|c|}{ Dependence O4 and O7c: hate / Ovisnost O4 i O7: mržnja } \\
\hline & Manager / Menadžer & Owner / Vlasnik & Employee / Zaposlenik & Line (sums) \\
\hline 0 & -5.93548 & 3.49380 & 2.44169 & 0.00 \\
\hline \multirow[t]{3}{*}{1} & 5.93548 & -3.49380 & -2.44169 & 0.00 \\
\hline & \multicolumn{4}{|c|}{ Dependence O4 and O7c: sadness / Ovisnost O4 i O7: tuga } \\
\hline & Manager / Menadžer & Owner / Vlasnik & Employee / Zaposlenik & Line (sums) \\
\hline 0 & -9.22581 & 6.92556 & 2.30025 & 0.00 \\
\hline 1 & 9.22581 & -6.92556 & -2.30025 & 0.00 \\
\hline
\end{tabular}

The statement in question 9 argued that, in the case of unknown decision-making situations, emotions such as fear, love or hate are a source of change in behaviour. $58.1 \%$ (219 managers) strongly agree with the statement and $17.2 \%$ (65 managers) agree. It follows that love, fear and hate are the reason for most managers to change their action and behaviour. We have connected this statement with hypothesis $H_{3}$. The hypothesis assumed that people are rational and their thinking is reasonable. However, these emotions are a source of cases where they change their behaviour in crucial situations. This hypothesis was partially confirmed by the given statement. In the previous section, where question 7 was statistically evaluated, it can be seen that these factors are a source of change in the behaviour of business managers.

With question 10, we wanted to find out whether managers try to guide their decision-making behaviour through self-control in thinking. Self-control in thinking is a factor showing how to manage a certain burden and effort that comes with decision-making. The manager must try to control himself, to be able to handle situations that are at some point a source of irrational behaviour. Self-control can also be considered as a certain personality characteristic of a person. Descriptive statistics show that $87 \%$ of managers can control themselves and guide their decision-making behaviour. $11.2 \%$ of managers are partially affected, but they agree with this statement. $0.5 \%$ (2 managers), who are clearly unable to guide their behaviour, did not agree. Hypothesis $H_{1}$ was linked to this question. We assumed that managers did not monitor their behaviour and decision-making and could not direct their behaviour to self-control. This hypothesis was refuted because managers agreed with the statement.

The statement in question 11, that behaviour is one of the important aspects in explaining economic decisions, is connected to hypothesis $H_{2}$. Human behaviour varies depending on several factors. Behavioural factors have been mentioned above. These are largely a source of behaviour change. They can change the expected results and, of course, they are also a source of wrong decisions. Following the results related to the statement, $78.8 \%$ (297 managers) strongly agree with this statement. This percentage of respondents is aware of changes in behaviour as well as of the possibility of deviations and errors that occur in financial decisions.

\subsection{Model concept}

3.2. Koncept modela

Based on the presented results of mathematicalstatistical research, we developed a model for determining the key behavioural factors that cause errors in the financial decision-making process of company managers (Figure 1). Then, we applied the first model to the second model of systematically occurring decision-making errors of managers for the purpose of eliminating wrong decisions. By connecting the two models (presented in Figure 1), we obtained a tool that can eliminate wrong decisions of company managers.

\section{DISCUSSION}

\section{RASPRAVA}

By directed statements, we aimed to point out that behavioural aspects can cause significant devia- 


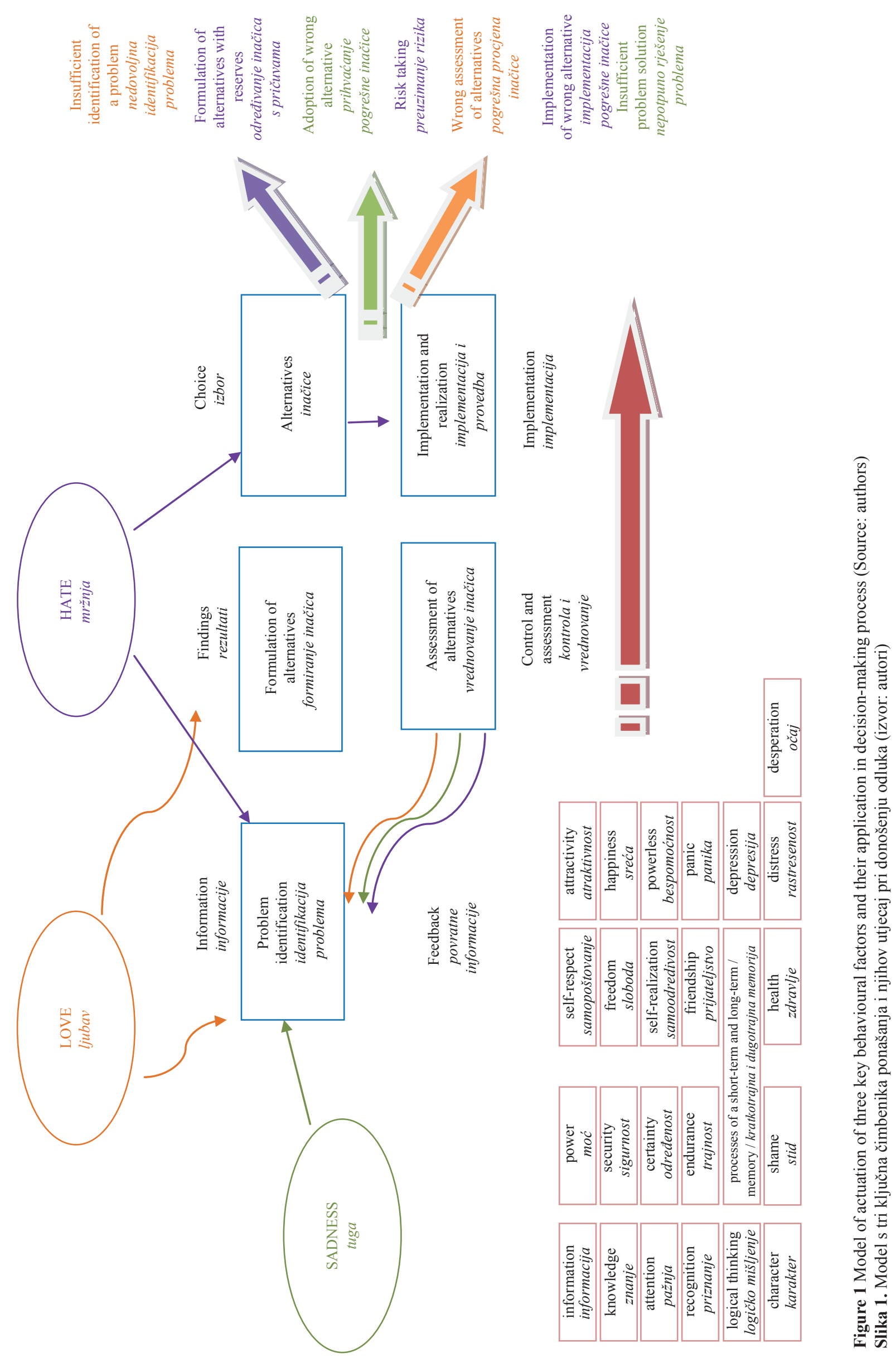


tions in the behaviour of managers and thus bring inaccurate to erroneous results in their decisions. Our findings focused on factors of behavioural finance, which are related to investment influence in decision-making in wood processing industry. We have discussed this topic with other authors (Dolan, 2002; Franco and Sanches, 2016; Virlics, 2013), also including developing countries (Asab et al., 2014). Baláž (2009) provided many incentives for discussion and questions about the essence, meaningfulness and topicality of behavioural economics. In the second statement, it is clear that intuition influences managers in the decision-making process when considering most of the answers. Nevertheless, if they have enough time to make decisions and are unsure of the outcome, they will rather rely on quantitative and analytical methods. However, the use of one's intuition is not refuted. Over the past several decades, evidence has shown that financial decision-making in the economy at all levels often departs from the predictions of models of rational information-processing (Frydman and Camerer, 2016). More than half of the managers stated that decisions based on their intuition brought profit-maximizing results. Managers also agree that, in the case of clear and well-structured problems, they can omit some steps in the decision-making process. In this case, we can make it clear that managers rely on their intuition. However, it is not clear to what extent and specifically which behavioural factors are the source of change in their behaviour. Due to this fact, we included specific behavioural factors divided into three groups among the statements. Thus each manager had the opportunity to choose the factors that most influence him when making decisions.

Following the previous statement, a question concerning the style of decision-making was included in the second part of the questionnaire. In the context of the sophistication of financial relationships, investment alternatives and risk, the human factor has become increasingly important in investor decision-making (Hitka et al., 2019; Lorincová et al., 2019; Wang and Ruhe, 2007). More than half of the managers reported a behavioural style of decision-making; however, each of the four options contained an answer. The ninth statement focused specifically on three categories of behavioural factors. It was fear, love and hate. This statement was supported by the hypothesis: Behavioural factors affect business decision making (Merigo, 2015; Tur-Porcar et al., 2018). Results of Shu et al., (2016) identify bereavement as an underexplored life experience that can significantly influence investors' performance and behaviour. From our research, it can be concluded that love and hate are decisive factors in changing behaviour. This has also been confirmed on the basis of the statistical dependence addressed in question 7.

The last two statements were aimed at manager's self-control in thinking and perception of behaviour. Both statements are linked and the managers are aware of their actions. They agreed that their behaviour influences economic decisions and try to prevent wrong decisions by applying self-control. Functional freedom depends on three compensatory dimensions: it is greatest when the decision-maker is highly rational, when the structure of the decision is highly underdetermined, and when the decision process is strongly based on conscious thought and reflection (Lau and Hiemisch, 2017).

Based on the findings and benefits of the issue, we recommend further examination of behavioural factors and their impact on the financial decision-making process of company managers. As this issue is current and interesting, we think that our results will be applicable to further research in the use of specific behavioural factors and their impact. We believe that our results can influence the perception of managers of wood processing enterprises and their future direction in the area of decision-making. We are convinced that thanks to the implemented empirical research, most managers will try to change their behaviour and think about their decisions.

\section{CONCLUSIONS 5. ZAKLJUČAK}

Decisions based on hypotheses resulting from the mathematical-statistical research in the wood processing industry are as follows:

We reject hypothesis $H_{1}$. Research shows that 87 $\%$ of managers are able to direct their behaviour and actions providing self-control in thinking.

Hypothesis $\mathrm{H}_{2}$ was confirmed. We can assume that managers are aware of their behaviour and perceive the changes resulting from financial decisions.

We can confirm the validity of hypothesis $H_{3}$. In the case of unknown decision-making situations, emotions such as fear, love or hate are a source of behavioural change. Two behavioural factors - love and hate, which are the source of change in the decisions of company managers, have been confirmed.

We reject hypothesis $H_{4}$. We could determine three key behavioural factors - love, hate and sadness, which affect the financial decision-making process of managers in the wood-processing enterprises.

\section{Acknowledgements - Zahvala}

This research has been supported by the Slovak Research and Development Agency, grant number APVV-20-0004, APVV-18-0520, APVV-18-0378, APVV-17-0456 and APVV-17-0583, by funds of KEGA project KEGA 005TU Z-4/2020 and project LignoPro - ITMS: 313011 T720.

\section{REFERENCES}

6. LITERATURA

1. Akerlof, G. A., Shiller, R. J., 2010: Živočišné pudy. Jak lidská psychologie ovlivňuje ekonomiku. Praha: Argo, Dokořán.

2. Antov, P.; Savov, V.; Neykov, N., 2020: Sustainable biobased adhesives for eco-friendly wood composites. A review. Wood Research, 65: 51-62.

https://doi.org/10.37763/wr.1336-4561/65.1.051062. 
3. Asab, Z. M.; Manzoor, S.; Naz, H., 2014: Impact of behavioural finance and traditional finance on financial decision-making process. Journal of Economics and Sustainable Development, 5 (18): 89-95.

4. Baker, K. H.; Nofsinger, J., 2010: Behavioural finance: investors, corporations, and markets. New Jersey: John Wiley.

5. Baker, M. P.; Ruback, R. S.; Wurgler, J., 2004: Behavioural corporate finance: A survey. In: Handbook of Corporate Finance: Empirical Corporate Finance, pp. 145185.

6. Baker, M.; Ruback, S. R.; Wurgler, J., 2007: Behavioural corporate finance: A survey. In: Handbook of Empirical Corporate Finance, Chapter 4. https://doi.org/10.1016/B978-0-444-53265-7.50018-4.

7. Baláž, V., 2009: Riziko a neistota. Karlova Ves: VEDA.

8. Bikas, E.; Jurevičiene, D.; Dubinskas, P.; Novickyte, L., 2013: Behavioural finance: The emergence and development trends. Procedia - Social and Behavioural Sciences, 82: 870-876.

https://doi.org/10.1016/j.sbspro.2013.06.363.

9. Dervishaj, B., 2018: Psychological biases, main factors of financial behaviour. European Journal of Natural Sciences and Medicine, 1(2): 25-35. https://doi.org/10.26417/ejnm.v1i2.p25-35.

10. Dolan, J. R., 2002: Emotion, cognition, and behaviour. Science, 298 (5596): 1191-1194. https://doi.org/10.1126/science.1076358.

11. Eckbo, B. E., 2007: Handbook of corporate finance. North-Holland, Elsevier.

12. Fairchild, R., 2010: Behavioural corporate finance: existing research and future directions. International Journal of Behavioural Accounting and Finance, 1 (4): 277-293. https://doi.org/10.1504/IJBAF.2010.032843.

13. Franco, M.; Sanches, C., 2016: Influence of emotions on decision-making. International Journal of Business and Social Research, 6(1): 40-62.

https://doi.org/10.18533/ijbsr.v6i1.908.

14. Frydman, C.; Camerer, C., 2016: The psychology and neuroscience of financial decision making. Trends in Cognitive Science, 20(9): 1-15. https://doi.org/10.1016/j.tics.2016.07.003.

15. Graham, J. R.; Harvey, C. R., 2001: The theory and practice of corporate finance: Evidence from the field. Journal of Financial Economics, 60 (2-3): 187-243. http://dx.doi.org/10.1016/S0304-405X(01)00044-7.

16. Hajdúchová, I.; Sedliačiková, M.; Halaj, D.; Krištofík, P.; Musa, H.; Viszlai, I., 2016: Slovakian forest-based sector in the context of globalization. BioResources, 11(2): 4808-4820. https://doi.org/10.15376/biores.11.2.4808-4820.

17. Halaj, D.; Sedliačiková, M.; Malá, D., 2018: Customer behavior on the Slovakian roundwood market: a case study. BioResources, 13 (3): 6003-6020._https:// doi:10.15376/biores.13.3.6003-6020.

18. Hitka, M.; Kucharčíková, A.; Starchoň, P.; Balážová, Ž.; Lukáč, M.; Stacho, Z., 2019: Knowledge and human capital as sustainable competitive advantage in human resource management. Sustainability, 11 (18): 4985. https://doi.org/10.3390/su11184985.

19. Kahneman, D., 2002: Maps of bounded rationality: A perspective on intuitive judgment and choice. Nobel prize lecture, 8, 351-401.

20. Kahneman, D.; Tversky, A., 1979: An analysis of decision under risk. Econometrica, 47(2): 263-291.

21. Kapoor, S.; Prosad, J. M., 2016: Behavioural finance: A review. Procedia Computer Science, 122: 50-54. https://doi.org/10.1016/j.procs.2017.11.340.
22. Kozel, R., 2006: Moderní marketingový výzkum: nové trendy, kvantitativní a kvalitativní metody a techniky, průbeh a organizace, aplikace $\mathrm{v}$ praxi, př́nosy a možnosti. Praha: Grada Publishing, a. s.

23. Laibson, D., 2009: Behavioural finance: Investment mistakes and solutions (online). https://scholar.harvard.edu/ laibson/publications/behavioral-finance-investment-mistakes-and-solutions (Accessed Oct. 13, 2018).

24. Lau, S.; Hiemisch, A., 2017: Functional freedom: A psychological model of freedom in decision-making. Behavioural Sciences, 7(3): 41. https://doi.org/10.3390/bs7030041.

25. Lehrer, J., 2011: The Science of Irrationality (online). Dow Jones Company Inc.: Wall Street Journal. https:// www.wired.com/2011/10/the-science-of-irrationality/ (Accessed Oct. 13, 2018).

26. Likert, R., 1932: A technique for the measurement of attitudes. Archives of psychology.

27. Lorincová, S.; Starchoň, P.; Weberová, D.; Hitka, M.; Lipoldová, M., 2019: Employee motivation as a tool to achieve sustainability of business processes. Sustainability, 11 (13): 3509. https://doi.org/10.3390/su11133509.

28. Merigo, M. J., 2015: Decision making under risk and uncertainty and its application in strategic management. Journal of Business Economics and Management, 16 (1): 93-116. https://doi.org/10.3846/16111699.2012.661758.

29. Merková, M.; Drábek, J.; Polách, J., 2011: Impact of investment on labour productivity growth in wood processing industry in Slovak Republic. Finance and the Performance of Firms in Science, Education and Practice. Zlín, pp. 324-332.

30. Merková, M.; Drábek, J.; Jelačić, D., 2012: Determinants of effects of foreign direct investment in terms of Slovak Republic and wood-processing industry of Slovakia. Drvna industrija, 63: 129-142. https://doi.org/10.5552/drind.2012.1136.

31. Merková, M.; Drábek, J., 2010: Effects and benefits of foreign direct investment for the development of woodprocessing industry. Wood processing and furniture manufacturing: present conditions, opportunities and new challenges. Vyhne, pp. 125-133.

32. Omarli, S., 2017: Which factors have an impact on managerial decision-making process? An integrated framework. Essays in Economics and Business Studies, 83-93. https://doi.org/10.18427/iri-2017-0068.

33. Pacáková, V.; Labudová, V.; Sipková, L'.; Šoltés, E.; Vojtková, M., 2009: Štatistické metódy pre ekonómov. Bratislava: Iura Edition.

34. Pompian, M. M., 2006: Behavioural finance and wealth management: How to build optimal portfolios that account for investor biases. New Jersey: John Wiley \& Sons, Inc.

35. Rehan, R.; Umer, I., 2017: Behavioural biases and investor decisions. Market Forces, 12 (2): 12-20.

36. Ricciardi, V.; Simon, H. K., 2000: What is behavioural finance? Business, Education \& Technology Journal, 2 (2): $1-9$

37. Ross, A. S., 2004: Neoclassical finance (online). http:// www.untag-smd.ac.id/files/Perpustakaan_Digital_1/FINANCE\%20Neoclassical\%20finance.pdf ${ }^{-}$(Accessed Oct. 24, 2018).

38. Schmidtová, J.; Vacek, V., 2013: Applied statistics. Zvolen: Technical University in Zvolen.

39. Sedaghati, B., 2016: Psychology of behavioural finance. International Journal of Humanities and Cultural Studies, 2665-2677.

40. Sedliačiková, M.; Vacek, V.; Sopková, E., 2015: How Slovak small and medium enterprises perceive financial controlling. Procedia - economics and finance. $4^{\text {th }}$ World 
conference on business, economics and management, WCBEM. Procedia Economics and Finance, 26: 82-85. https://doi: 10.1016/S2212-5671(15)00842-4.

41. Sewell, M., 2011: History of the efficient market hypostudy (online). UCL Department of Computer Science. http://www.cs.ucl.ac.uk/fileadmin/UCL-CS/images/Research_Student_Information/RN_11_04.pdf (Accessed Oct. 24, 2018).

42. Shefrin, H., 2001: Behavioural corporate finance. Applied Corporate Finance, 14 (3): 113-126. https://doi.org/10.1111/j.1745-6622.2001.tb00443.x.

43. Shefrin, H., 2005: A behavioural approach to asset pricing. Academic Press.

44. Shu, T.; Sulaeman, J.; Yeung, P. E., 2016: Does Sadness Influence Investor Behaviour? SSRN Electronic Journal, 1-35. http://dx.doi.org/10.2139/ssrn.2658815.

45. Smith, A., 2012: The theory of moral sentiments. Courier Corporation.

46. Thaler, R. H., 2005: Advances in behavioral finance, Vol. II. Princeton University Press.

47. Thaler, H. R.; Sunstein, R. C., 2008: Nudge: Improving decisions about health, wealth, and happiness. Yale University Press.

48. Tur-Porcar, A.; Roing-Tierno, N.; Llorca-Mestre, A., 2018: Factors affecting entrepreneurship and business sustainability. Sustainability, 10 (2): 452. https://doi.org/10.3390/su10020452.

49. Tversky, A.; Kahneman, D., 1974: Judgment under uncertainty: Heuristics and biases. Science, 185 (4157): 1124-1131.

50. Verešová, M.; Daniel, J.; Sarmány-Schuller, I.; Szabó, I.; Popelková, M., 2014: Prehl'ad všeobecnej psychológie. Bratislava: ARIMES.
51. Virlics, A., 2013: Emotions in economic decision making: a multidisciplinary approach. Procedia-Social and Behavioural Sciences, 92: 1011-1015. https://doi.org/10.1016/j.sbspro.2013.08.792.

52. Wang, Y.; Ruhe, G., 2007: The cognitive process of decision making. International Journal of Cognitive Informatics and Natural Intelligence, 1 (2): 73-85. https://doi.org/10.4018/jcini.2007040105.

53. Weinstein, N. D., 1980: Unrealistic optimism about future life events. Journal of Personality \& Social Psychology, 39 (5): 806-820. https://doi.org/10.1037/0022-3514.39.5.806.

54. Záborský, 2017: Ako sa zrodila behaviourálna ekonómia (online). https://www.trend.sk/trend-archiv/ako-zrodilabehavioralna-ekonomia (Accessed Oct. 27, 2018).

55. ***FAW, 2018: Financial Analyst Warrior: What is the difference between Traditional Finance and Behavioural Finance? (online). https://www.financialanalystwarrior. com/difference-traditional-finance-behavioural-finance/ First published 2018 (Accessed Oct. 25, 2018).

\section{Corresponding address:}

\section{Prof. MARIANA SEDLIAČIKOVÁ, PhD}

Technical University in Zvolen Faculty of Wood Sciences and Technology Department of Economics, Management and Business T. G. Masaryka 24, SK-960 01 Zvolen, SLOVAKIA e-mail: sedliacikova@tuzvo.sk 